\title{
Praktik Ijarah Jasa Pengairan Sawah dalam Pandangan Hukum Ekonomi Syariah (Studi di Kota Metro)
}

\author{
Ambariyani $^{1 \mathrm{a}}$ dan Wiwik Damayanti $^{1 \mathrm{~b}}$ \\ ${ }^{1}$ Institut Agama Islam Ma'arif NU Metro Lampung \\ Email : a ambariyani@yahoo.co.id, \\ bwiwikdamayanti1983@gmail.com
}

\begin{abstract}
\end{abstract}
Law Number 77 Year 2001 about irrigation stated that irrigation is the effort of providing and setting of water to support agriculture. Providing of irrigation in Metro City was needed by farmers community, especially in the rice field by cooperation way, cooperation was done to gain profits. The farmers got the benefits of water availability and the irrigation wages got benefit from farmers. They are $5 \mathrm{~kg}$ of rice from harvest and $R p .2500$ money from $1800 \mathrm{~m}$. Implementation of service contracts in Metro City was orally, there was no term written agreement. service contracts that occur in Metro City was based on mutual trust between the two party. Therefore, there is much to be investigated further about the service contracts that occurred in Metro City, both in contract terms and in sharia economic law theory terms. As for the problem is: How if there is a service contract violation committed by one party?. The research problems in this research are how the process of irrigation service wage in Metro City is and whether the service contract applied in Metro City is already in accordance with the muamalah Islam values?

The purpose of this research is to know and analyze the wage service process of irrigation field in Metro City and to know Sharia Economic Law view about the service contract in Metro City.

Research conducted by this researcher included into field research. Field research is direct research conducted in the field or on the respondents directly. This research described object and analyzed it. Data source used is primary data source and secondary data source. Methods of data collection used interviews, observation and 
documentation. Qualitative analysis is a data analysis technique that used appropriate information sources to assist in the research process.

In this research the researcher concluded that the implementation of service contracts in Metro City is one form of cooperation that may be done. The availability of water in farming can affect live continuance to farmers; with the pattern of $5 \mathrm{~kg}$ rice payment and money of Rp.2500 from $1800 \mathrm{~m}$ and it was given after the farmer sells the harvest. Implementation of service contracts that occur in the Metro City when reviewed with ijarah theory is with the rental of energy to irrigate during the planting period until the harvest, but with a breach of contract made by one of the parties caused ijarah become imperfect and become fasid.

Keywords: Praktik Ijarah, Jasa Pengairan Sawah, Hukum Ekonomi Syariah.

\section{Abstrak}

Undang-Undang Nomor 77 Tahun 2001 tentang irigasi, menyebutkan bahwa irigasi adalah usaha penyediaan dan pengaturan ait untuk menunjang pertanian. Penyediaan irigasi di Kota Metro sangat di butuhkan untuk memenuhi kebutuhan masyarakat petani khususnya dalam bidang persawahan dengan cara kerjasama. Kerjasama dilakukan untuk memperoleh keuntungan. Pihak petani memperoleh keuntungan berupa kesediaan air dan pihak irigasi memperoleh upah dari hasil panen petani yaitu5 $\mathrm{kg}$ padi dan uang sebesar Rp.2500 dari 1/4 bahu. Pelaksanaan akad jasa di Kota Metro terjadi secara lisan, tidak ada istilah surat perjanjian tertulis, akad jasa yang terjadi di Kota Metro hanya berdasarkan saling percaya antara kedua belah pihak. Oleh sebab itu banyak yang harus diteliti lebih lanjut mengenai akad jasa yang terjadi di Kota Metro tersebut, baik dari segi akad maupun dari segi teori hukum ekonomi syariah. Adapun yang menjadi permasalahannya adalah: bagaimana jika terjadi pelanggaran akad jasa yang dilakukan oleh salah satu pihak?. Rumusan masalah dalam penelitian ini adalah bagaimana proses terjadinya upah jasa pengairan di Kota Metro dan apakah akad jasa yang 
diterapkan di Kota Metro tersebut sudah sesuai dengan nilainilai muamalah Islam?.

Tujuan dari penelitian ini untuk mengetahui dan menganalisis proses upah jasa pengairan sawah di Kota Metro dan untuk mengetahui pandangan Hukum Ekonomi Syari'ah tentang akad jasa di Kota Metro.

Penelitian yang dilakukan oleh peneliti ini termasuk kedalam jenis penelitian lapangan. Penelitian lapangan adalah penelitian yang langsung dilakukan di lapangan atau langsung pada responden. Penelitian ini menggambarkan dan mendeskripsikan keadaan suatu obyek kemudian menganalisisnya. Sumber data yang digunakan adalah sumber data primer dan sumberdata sekunder. Metode pengumpulan datanya menggunakan wawancara, observasi dan dokumentasi. Analisis kualitatif merupakan teknik analisis data yang menggunakan sumber informasi yang sesuai untuk membantu dalam proses penelitian.

Dalam penelitian ini penulis mengambil kesimpulan bahwa pelaksanaan akad jasa di Kota Metro merupakan salah satu bentuk kerjasama yang boleh dilakukan. Tersedianya air pada masyarakat petani dalam bercocok tanam dapat berpengaruh pada kelangsungan hidup masyarakat yang mayoritas berpenghasilan dari pertanian. Dengan pola pembayaran $5 \mathrm{~kg}$ padi dan uang sebesar Rp.2500 dari 1/4 bahu dan diberikan setelah petani menjual hasil panen tersebut. Pelaksanaan akad jasa yang terjadi di Kota Metro bila ditinjau dengan teori ijarah yaitu dengan persewaan tenaga untuk mengairi selama masa tanam sampai masa panen, tetapi dengan adanya pelanggaran akad yang dilakukan oleh salah satu pihak yang berakad menyebabkan rukun ijarah menjadi tidak sempurna dan menjadi akad yang fasid.

Kata Kunci: Praktik Ijarah, Jasa Pengairan Sawah, Hukum Ekonomi Syariah.

\section{A. Pendahuluan}

\section{Latar Belakang Masalah}

Manusia adalah makhluk bermasyarakat yang tidak dapat hidup sendiri. Manusia memerlukan pertolongan satu 
dengan yang lainnya dan persekutuan persekutuan dalam memperoleh kemajuan. Untuk mendapatkan rezeki karunia dari Allah, banyak cara yang dilakukan orang untuk memenuhi kebutuhannya. Ada yang berusaha secara individu ada pula yang berusaha secara berkelompok.

Kehadiran agama Islam yang dibawa Nabi Muhammad SAW diyakini dapat menjamin terwujudnya kehidupan manusia yang sejahtera lahir dan batin. Yang di dalamnya terdapat berbagai petunjuk tentang bagaimana seharusnya manusia itu menyikapi hidup dan kehidupan secara lebih bermakna dalam arti yang seluas luasnya. Petunjuk petunjuk agama mengenai berbagai kehidupan manusia sebagaimana terdapat didalam sumber ajarannya, Al Quran dan hadis, tampak amat ideal dan agung. Islam mengajarkan kehidupan yang dinamis dan progresif.

Menghargai akal pikiran melalui pengembangan ilmu pengetahuan dan teknologi, bersikap seimbang dalam memenuhi kebutuhan material dan spiritual, senantiasa mengembangkan kehidupan sosial, menghargai waktu, bersikap terbuka, demokrasi, berorientasi pada kualitas, egaliter, kemitraan, mengutamakan persaudaraan, berakhlak mulia, dan sikap sikap positif lainnya. ${ }^{1}$

Praktik irigasi juga di atur dalam Pasal 1 ayat (3) Undang-Undang Nomor 77 Tahun 2001 Tentang Irigasi, menyebutkan bahwa irigasi adalah usaha penyediaan dan pengaturan air untuk menunjang pertanian, yang jenisnya meliputi irigasi air permukaan, irigasi air bawah tanah, irigasi pompa, dan irigasi tambak. Pasal 5 ayat (1), menyebutkan, untuk menjamin terselenggaranya pengelolaan irigasi yang efektif serta dapat memberikan manfaat yang sebenar-benarnya kepada masyarakat petani, pengelolaan irigasi dilaksanakan dengan mengoptimalkan pemanfaatan air permukaan dan air bawah tanah secara terpadu. ${ }^{2}$

Mengenai volume air yang harus dialirkan kedaerah dataran rendah untuk irigasi, Imam Asy-Syafi'I berpendapat

1 Abuddin Nata, Metodologi Studi Islam Jakarta: Rajawali Pers, 2010, h. 1

${ }^{2}$ Undang-undang Nomor 77 Tahun 2001 tentang Irigasi. Pasal 1 ayat (3) dan Pasal 5 ayat (1) 
bahwa hanya air dalam jumlah lebih yang harus dibiarkan mengalir. Artinya bila tanah pertama seseorang belum terdiri sedalam satu mata kaki maka dirinya tidak berkewajiban mengalirkan air ketanah. ${ }^{3}$

Sedangkan pengertian akad sendiri adalah pertalian ijab (peryataan melakukan ikatan) dan kabul (peryataan penerimaan) sesuai dengan kehendak syariat yang berpengaruh kepada objek perikatan. ${ }^{4}$ Objek yang menjadi pokok permasalahan adalah upah. Upah merupakan instrumen yang dapat digunakan untuk mengukur sejauh mana kita memahami dan mewujudkan karakter sosial kita. Karena upah pada dasarnya bukan merupakan persoalan yang hanya berhubungan dengan uang, melainkan merupkan persoalan yang lebih berkaitan dengan penghargaan manusia terhadap sesamanya. Dalam hal penghargan berarti bagaimana manusia memandang dan menghargai kehadiran orang lain dalam kehidupannya, atau bagaimana memahami keberagaman dalam masyarakat. Perspektif sederhana yang sering muncul dalam konteks ini adalah sesama manusia adalah sarana bagi kelangsungan hidup manusia, atau tujuan masyarakat. Jika pengertian keberagaman kehidupan manusia sebagai sarana, maka sering kali manusia memperlakukan suatu masyarakat sebagai sebuah barang. ${ }^{5}$

Terkait dengan hal diatas, dapat ditegaskan bahwa bisnis juga memiliki etika serta aturan (kode etik). Sebaiknya bisnis untuk kehidupan manusia, bukan sebaliknya manusia diciptakan untuk kepentingan bisnis. Bisnis dilakukan bukan semata-mata untuk mengeksploitasi manusia di satu sisi dan menumpuk keuntungan disisi lain. Akan tetapi bisnis dilakukan untuk kesejahteraan umat manusia.

Praktik Upah pengairan yang terjadi di masyarakat Kota Metro masih menggunakan cara-cara tradisional, masyarakat masih menggunakan modal kepercayaan, saling mempercayai terhadap terjadinya perjanjian bagian atau upah jasa yang diberikan petani kepada pihak pengelola irigasi,

\footnotetext{
${ }^{3}$ Ija Suntana, Politik Ekonomi Islam (Siyasah Maliyah), Bandung : Cv Pustaka Setia, 2010, h. 210

4 Abdullah Rahman Ghazali, Fiqih Muamalah, yogyakarta : Kencana Prenada Media Group, h. 51

${ }^{5}$ Ibid. h. 52
} 
setelah perjanjian tersebut disepakati secara lisan oleh masyarakat, maka muncul sebuah hak dan kewajiban antara kedua belah pihak. Masyarakat petani mempunyai hak untuk mendapatkan air dari pengelola irigasi dan berkewajiban memberikan hasil panen yang telah disepakati kepada pengelola irigasi, sedangkan pengelola irigasi mempunyai hak untuk memperoleh hasil panen masyarakat petani sesuai dengan kesepakatan dan berkewajiban memberikan air pada sawah masyarakat petani. ${ }^{6}$

Sesuai dengan kesepakatan bahwa pada waktu panen petani memberikan $5 \mathrm{~kg}$ padi dan uang Rp.2500 dari $1 / 4$ bau kepada pihak pengelola irigasi sebagai upah atau ujrah. Pembagian tersebut dilakukan ketika petani sudah panen. Aturan pembagiannya ialah dengan cara pihak petani mendatangi rumah petugas irigasi, kemudian petani memberikan bagian $5 \mathrm{~kg}$ padi dan uang Rp. 2500 dari $1 / 4$ bau. $^{7}$

Adapun usaha masyarakat yang dilakukan dengan istilah upah jasa dikategorikan akad yang sering kita kenal yaitu Ijarah. Ijarah adalah akad pemindahan hak (manfaat) suatu barang atau jasa dalam waktu tertentu dengan adanya pembayaran upah (ujrah), tanpa diikuti dengan pemindahan kepemilikan atas barang itu sendiri. ${ }^{8}$ objek dalam akad Ijarah adalah manfaat itu sendiri bukan bendanya. Penulis melihat ada beberapa hal yang telah terjadi seperti adanya ketidak jelasan akad dan tindakan yang tidak sesuai dengan perjanjian seperti yang telah dijanjikan dalam hal upah.

\section{Rumusan Masalah}

Berdasarkan latar belakang masalah yang sudah diuraikan diatas, maka penulis dapat merumuskan permasalahan sebagai berikut :pertama, Bagaimana proses Upah Jasa pengairan sawah di Kota Metro? Dan yang kedua, Bagaimana pandangan Hukum Ekonomi Syariah tentang praktik Ijarah jasa pengairan sawah di Kota Metro?

${ }^{6}$ Wawancara dengan Bapak Sumarno, Ketua Irigasi desa, 20 Februari 2017

${ }^{7}$ Wawancara dengan bapak Narto, Petani padi, 21 Februari 2017

${ }^{8}$ Dimyauddin djuwani, Pengantar Fiqih Muamalah, Yogyakarta : Pustaka Pelajar, 2008. h. 153 
Mengingat pentingnya metode dalam penelitian, maka dalam usaha menyusun penelitian ini digunakan cara-cara berfikir dalam rangka membahas pokok-pokok permasalahan yang di rumuskan agar penelitian ini dapat terlaksana secara objektif ilmiah dan mencapai hasil yang optimal.

\section{Metode Penelitian}

a. Jenis Penelitian

Penelitian ini termasuk ke dalam penelitian lapangan (field research). Penelitan lapangan merupakan penelitian yang langsung dilakukan atau pada responden, 9yang bertujuan untuk mempelajari secara intensif tentang latar belakang keadaan sekarang, interaksi lingkungan suatu unit sosial, individu, kelompok, lembaga atau masyarakat.10 Penelitian ini bersifat deskriptif kualitatif, yaitu menggambarkan dan mendeskripsikan keadaan atau suatu objek kemudian menganalisisnya.11 Penelitian deskriptif dapat diartikan pula sebagai penelitian yang mempelajari masalah-masalah dalam masyarakat, serta tata cara dan situasi-situasi yang berlaku, termasuk hubungan-hubungan, kegiatan-kegiatan, sikap-sikap, pandangan-pandangan, serta proses yang sedang berlangsung dan pengaruh-pengaruh dari fenomena.

b. Sumber Data

Data merupakan hasil pencatatan penelitian, baik yang berupa fakta atau angka. Jadi data dapat di artikan segala fakta angka yang di jadikan bahan untuk menyususn informasi, sedangkan informasi adalah hasil pengolahan yang dapat di pakai untuk suatu keperluan.

Dengan metode ini penulis melakukan penelitian guna mengumpulkan data yang bersumber dari subyek yang diteliti. Penelitian ini pada hakikatnya merupakan

${ }^{99}$ M. Iqbal Hasan, Pokok-pokok Materi Metodologi Penelitian dan Aplikasinya, Jakarta : Ghalia indonesia, 2002, h. 11

${ }^{10}$ Cholid Narbuko, Abu Achmadi, Metodologi Penelitian, Cet. 9, (Jakarta : Bumi Aksara, 2008), h. 46

${ }^{11}$ Sumadi Suryabrata, Metodologi Penelitian, Jakarta : Rajawali Press, 1990, h. 1 
metode untuk menemukan secara khusus dari realitas yang tengah terjadi di tengah masyarakat yaitu $:^{12}$

a) Data Primer yaitu sumber utama yang dijadikan bahan penelitian dalam penulisan ini, karena ini penelitian lapangan, maka yang menjadi sumber utama adalah Ibu Ulfa (Perwakilan dinas PU Metro), Bapak sumarno (pengelola irigasi desa), malek (petani), ustz Arkom (tokoh agama) dan praktek akad upah jasa yang ada di Kota Metro.

b) Data Sekunder yaitu sumber data yang menjadi bahan penunjang dan melengkapi analisis. Dalam penelitian ini yang dijadikan sumber sekunder adalah buku-buku referensi yang yang akan melengkapi hasil wawancara, observasi dan dokumentasi yang telah ada.

\section{c. Teknik Pengumpulan Data}

Dalam penelitian ini penulis menggunakan beberapa metode untuk mendapatkan data, metode yang digunakan diantaranya:

\section{a) Metode Observasi}

Observasi adalah pengamatan dan pencatatan yang sistematis terhadap gejala-gejala yang diteliti. ${ }^{13}$ Dengan teknik ini peniliti mengamati dan mencatat hal-hal yang perlu, fenomena-fenomena yang diselidiki, yaitu proses pemberian upah dalam pengairan sawah.

Metode ini mengumpulkan data dengan pengamatan dan pencatatan secara sistematik. Digunakan untuk mengamati gambaran mengenai upah jasa dalam pengairan, gambaran umum lokasi penelitian, sarana-prasarana yang digunakan dan yang terutama mengenai proses pengairansawah di Kota Metro.

12 Saifuddin Azwar, Metodologi Penelitian, Yogyakarta: Pustaka Pelajar, 1999, h. 91

13 Husain Usman dan Purnomo Setiady Akbar, Metodologi Penelitian Sosial, Jakarta : Bumi Aksara, 2000, h. 54 
Peneliti mengamati berbagai peristiwa dengan cara terlibat langsung dilokasi penelitian. Sehingga dengan teknik ini, akan membantu penulis untuk mengetahui bagaimana proses ijarah yang sebenarnya.

\section{b) Metode Wawancara}

Wawancara adalah salah satu bagian terpenting dari setiap surve, tanpa wawancara peneliti akan kehilangan informasi yang hanya dapat diperoleh dengan jalan bertanya langsung kepada informan. Data semacam itu merupakan tulang punggung penelitian surve. ${ }^{14}$

Metode ini digunakan untuk mendapatkan informasi dari narasumber, narasumber yang dimaksud dalam kegiatan penelitian ini adalah beberapa petani pemilik sawah yang menggunakan air irigasi, pengurus program irigasi, tokoh tokoh masyarakat kota metro setempat.

\section{c) Metode Dokumentasi}

Metode pengumpulan data melalui peninggalan tertulis, terutama berupa arsip-arsip dan termasuk buku-buku tentang pendapat, teori, dalil, atau hukum, dan lain-lain yang berhubungan dengan masalah. ${ }^{15}$

\section{d. Analisis Data}

Dalam pembahasan hasil penelitian ini penyusun menggunakan analisa deskriptif yakni digunakan dalam mencari dan mengumpulkan data, menyusun dan menggunakan serta menafsirkan data yang sudah ada. Yang bertujuan untuk memberikan deskripsi mengenai subyek penelitian berdasarkan data yang diperoleh dari kelompok subyek yang diteliti. Adapun metedo yang digunakan antara lain metode:

${ }^{14}$ Masri Singaribun dan Sofian Effendi, Metode Penelitian Survei, Yogyakarta : Pusat Penelitian dan studi kependudukan Universitas Gajah Mada, 1981, h. 189

${ }^{15}$ Beni Ahmad Saebani, Metode Penelitian, (Bandung: Pustaka setia, 2008), h. 191 
a) Induktif.

yaitu suatu cara yang berangkat dengan menggunakan kenyataan- kenyataan yang khusus dari hasil riset kemudian diakhiri dengan kesimpulan yang bersifat umum.

\section{b) Deduktif.}

yaitu suatu cara berfikir yang diawali dengan mengunakan teori-teori dan dalil-dalil yang bersifat umum kemudian dikemukakan kenyataan yang bersifat khusus dari hasil riset.

\section{B. Kjian Teori}

\section{Pengertian Ijarah}

Kata Ijarah secara bahasa berarti al-ajru yaitu "imbalan terhadap suatu pekerjaan" dan "pahala". Dalam bentuk lain, kata ijarah juga bias dikatakan sebagai nama bagi al-ujrah yang berarti upah atau sewa, selain itu arti lain dari al-ajru tersebut adalah " ganti" (al-iwadh). Baik ganti itu diterima dengan didahului oleh akad atau tidak. ${ }^{16}$

Ijarah didefinisikan sebagai hak untuk memperoleh manfaat-manfaat tersebut bias berupa jasa atau tenaga orang lain, dan bias pula manfaat yang berasal dari suatu barang atau benda. Semua manfaat jasa dan orang tersebut dibayar dengan sejumlah imbalan tertentu. ${ }^{17}$

Sedangkan menurut istilah beberapa ulama' mendefinisikan sebagai berikut $:^{18}$

1) Ulama' Hanafiyah mendefinisikannya dengan :

"Transaksi terhadap suatu manfaat dengan imbalan"

2) Ulama' Syafi'iyah mendefinisikan dengan :

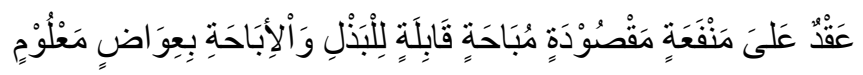

16 Ismail Nawawi, Fiqih Muamalah, Bogor : Ghalia Indonesia, 2012, h. 185

${ }^{17}$ Fathurrahman, OP.,Cit.,h. 150-151

${ }^{18}$ Rachmat Syafe'i, OP.,Cit., h. 121 
"Transaksi terhadap suatu manfa'at yang dituju tertentu, bersifat mubah dan boleh dimanfaatkan dengan imbalan tertentu".

3) Ulama' Malikiyah dan Hanabilah mendefinisikan dengan :

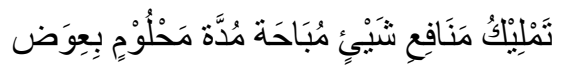

"Pemilikan manfa'at sesuatu yang dibolehkan dalam waktu tertentu dengan suatu imbalan".

Ijarah (sewa menyewa) dapat diartikan sebagai kontrak kerja yang maksudnya adalah "suatu jenis akad untuk mengambil manfaat dengan jalan penggantian", dari pengertian tersebut terlihat bahwa yang dimaksud dengan sewa menyewa itu adalah pengambilan manfaat suatu benda, jadi dalam hal ini dengan terjadinya peristiwa sewa menyewa, yang berpindah hanyalah manfaat dari benda yang disewakan, dalam hal ini dapat berupa manfaat barang seperti kendaraan, rumah dan manfaat karya seperti pemusik, bahkan dapat juga berupa karya pribadi seperti pekerja. ${ }^{19}$

Menurut fatwa Dewan Syariah Nasional (DSN), ijarah adalah akad pemindahan hak guna (manfaat) atas suatu barang atau jasa dalam waktu tertentu melalui pembayaran sewa atau upah, tanpa diikuti dengan pemindahan kepemilikan barang itu sendiri. Sedangkan menurut Bank Indonesia, ijarah adalag sewa menyewa atas manfaat suatu barang dan / atau jasa antara pemilik objek sewa dengan penyewa untuk mendapatkan imbalan berupa sewa atau upah bagi pemilik objek sewa. ${ }^{20}$

ijarah adalah akad pengalihan hak manfaat atas barang atau jasa melalui pembayaran upah sewa, tanpa diikuti dengan pengalihan kepemilikan atas barang itu sendiri. Transaksi ijarah didasarkan pada adanya pengalihan hak manfaat. Pada prinsipnya ini hampir sama dengan jual beli. Perbedaan anatar keduanya dapat dilihat pada dua hal yaitu,

a. Pada objek akad

${ }^{19}$ Drs. H. Chairuman Pasaribun dan Suhrawardi K.Lubis, SH. Hukum Perjanjian dalam Islam, Jakarta : Sinar Grafika, 1996, h. 52

${ }^{20}$ Fathurrahman Djamil, OP.,Cit., h. 151 
Objek akad jual beli adalah barang atau benda riil, sedangkan objek pada ijarah adalah jasa dari suatu pekerjaan atau manfaat dari suatu barang.

b. Pada penetapan batas waktu

Pada jual beli tidak ada pembatasan waktu memiliki objek transaksi, sedangkan kepemilikan pada ijarah untuk jangka waktu tertentu. Dalam ijarah tidak ada perubahan kepemilikan, tetapi hanya perpindahan hak guna saja dari yang yang menyewakan kepada penyewa.

Ijarah secara terminologis adalah transaksi atas suatu manfaat yang mubah yang berupa barang tertentu atau yang dijelaskan sifatnya dalam tanggungan dalam waktu tertentu, atau transaksi atas suatu pekerjaan yang diketahui dengan upah yang diketahui pula. ${ }^{21}$

Ijarah mempunyai peranan penting dalam kehidupan sehari-hari, karena kita tidak sanggup mengerjakan dan menyelesaikan urusan kita dengan kemampuan kita sendiri. Karena itu kita terpaksa menyewa tenaga atau mempekerjakan orang lain yang mampu melakukannya dengan imbalan pembayaran yang disepakati kedua belah pihak atau menurut adat kebiasaan yang berlaku.

Jumhur ulama fiqh berpendapat bahwa ijarah adalah menjual manfaat dan yang boleh disewakan adalah manfaatnya bukan bendanya. Oleh karena itu, mereka melarang menyewakan pohon untuk diambil buahnya, domba untuk diambil susunya, sumur untuk diambil airnya, sebab semua itu bukan manfaatnya, tetapi bendanya. ${ }^{22}$

Syari'at Islam memikulkan tanggung jawab bagi kedua belah pihak. Pihak pekerja yang telah mengikat kontrak, wajib melakukan pekerjaan itu sesuai dengan isi kontraknya, dan pihak pengusaha wajib memberikan upah atas pekerjaannya.

21 Abdullah bin Muhammad Ath-Thayyar, Ensiklopedi Fiqih Muamalah (dalam pandangan 4 madzhab), Yogyakarta : Maktabah AlHanifah, 2014, h. 311

${ }^{22}$ Rachmat Syafe'I, OP.,Cit., h. 122 


\section{Rukun dan Syarat Ijarah}

\section{a. Rukun Ijarah}

Ijarah dalam Islam akan dianggap sah apabila memenuhi rukun-rukunnya dan penulis menyimpulkan bahwa rukun ijarah adalah sebagaima yang termaktub dalam rukun jual beli sebagai berikut :

\section{1) Adanya ijab dan qabul (shighah)}

Ijab dan qabul adalah suatu ungkapan antara dua orang yang menyewakan `suatu barang atau benda, hal ini sesuai dengan pendapat Sayyid Sabiq bahwa : Ijarah menjadikan ijab qabul dengan memakai lafadz sewa atau kuli yang berhubungan dengannya atau dengan lafadz atau ungkapan apa saja yang dapat menunjukkan hal tersebut.23

Ijab adalah pernyataan pihak pertama mengenai isi perikatan yang diinginkan sedangkan qabul adalah peryataan pihak kedua untuk menerimanya. Ijab dan kabul itu diadakan dengan maksud untuk menunjukkan adanya sukarela timbal balik terhadap perikatan yang dilakukan oleh kedua belah pihak yang bersangkutan.

Shighah transaksi ijarah adalah sesuatu yang digunakan untuk mengungkapkan maksud muta'aqidain, yakni berupa lafal atau sesuatu yang mewakilinya, seperti lafal menyewa, mempekerjakan, dan lain sebagainya.

Ijab dan qabul terjadi antara dua pihak dengan sukarela, dan menimbulkan kewajiban atas masingmasing secara timbal balik, hal ini sesuai dengan firman Allah SWT dalam surat An-Nisa' ayat 29 :

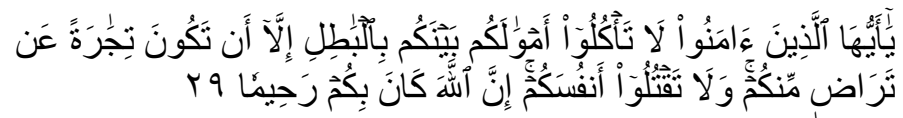

${ }^{23}$ Sayyid Sabiq, Fiqh Sunnah juz 13, alih bahasa H. Kamaluddin A. Marzuki, Bandung : PT. Al-Ma'arif, 1988, h. 11

24 Abdullah bin Muhammad Ath-Thayyar, OP.Cit (dalam pandangan 4 madzhab), h. 316 
Artinya : "Hai orang-orang yang beriman, janganlah kamu saling memakan harta sesamamu dengan jalan yang batil, kecuali dengan jalan perniagaan yang berlaku dengan suka sama suka diantara kamu. Dan janganlah kamu membunuh dirimu; Sesungguhnya Allah adalah Maha penyayang kepadamu."(QS. AnNisa':29)

2) Adanya dua pihak yang mengadakan akad(Muta'aqidain).

Rukun yang kedua dari ijarah adalah adanya perjanjian ijarah yaitu adanya akad atau orang yang melakukan akad, baik itu orang yang menyewakan atau orang yang akan menyewa barangnya.

Suatu akad akan dinamakan akad sah apabila terjadi pada orang-orang yang berkecakapan, objeknya dapat menerima hukum akad dan akad itu tidak terdapat hal-hal yang menjadikannya dilarang syara'ditinjau dari rukun-rukunya maupun pelaksanaannya. $^{25}$

Untuk rukun yang kedua ini para ulama sepakat bahwa kedua belah pihak yang melakukan akad harus memenuhi syarat sebagai berikut yaitu :

a) Keduanya harus berkemampuan yaitu harus berakal dan dapat membedakan antara yang baik dan yang buruk atau antara yang haq dan yang bathil, maka akadnya menjadi sah jika itu terpenuhi. Jika salah satu yang berakad itu gila atau anak kecil yang belum dapat membeda-bedakan antara yang haq dan yang bathil, maka akadnya idak sah. ${ }^{26}$

b) Keduanya melaksanakan transaksi ijarah secara suka sama suka. Jika ada paksaan atau terjadi paksaan, maka ijarah tidak sah.

Firman Allah QS.An-Nisa ayat 5 :

\footnotetext{
${ }^{25}$ Ibid, h. 317

${ }^{26}$ Sayyid Sabiq, OP.,Cit., h. 11
} 


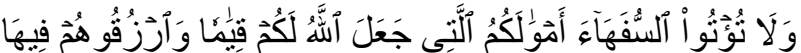

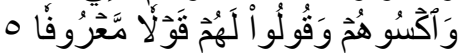

Artinya : "Dan janganlah kamu serahkan pada orang-orang yang belum sempurna akalnya, harta (mereka yang ada dalam kekuasaannya) yang dijadikaan Allah sebagai pokok kehidupan”. ( QS.AnNisa ayat 5).

Maksut ayat diatas adalah apabila harta benda tidak boleh diserahkan kepada orang yang belum berakal sempurna, maka ini berarti bahwa orang yang tidak ahli itu tidak boleh melakukan akad (ijab dan qabul).

Akad akan batal apabila terjadi pada orangorang yang tidak memenuhi syarat kecakapan atau obyeknya tidak dapat menerima hukum akad sehingga dengan demikian pada akad itu terdapat hal-hal yang menjadikannya dilarang oleh syara'.

1) Adanya objek akad

Rukun yang ketiga adalah harus ada barang yang dijadikan obyek untuk akad. Ma'qud alaih dijadikan rukun karena kedua belah pihak agar mengetahui wujud barangnya, sifat, keadannya, serta harganya. Sesuatu yang dijadikan obyek perjanjian kontrak kerja adalah berupa tenaga manusia atau keterampilan, karena tanpa adanya obyek maka tidak akan terwujud suatu akad, hal ini untuk menghindari adanya unsur penipuan dalam bidang pekerjaan dan pemberian upah. ${ }^{27}$

Ada lima syarat bagi ma'qud'alaih, yaitu sebagai berikut :

a) Manfaat barang yg disewakan

b) Ijarah hanya pada manfaat barang yang di transaksikan, bukan untuk menghabiskan atau merusak barang tersebut karena ijarah tidak sah kecuali pada manfaat suatu barang, sedangkan barangnya tetap ada.

${ }^{27}$ Sayyid Sabiq, Ibid, h. 13 
c) Manfaat pada ijarah adalah sesuatu yang mubah.

d) Manfaat barang yang disewakan dapat diperoleh secara hakiki dan syar'i. jadi, tidak sah menyewakan binatang yang melarikan diri, dan sebagainya.

e) Manfaat sesuatu yang disewakan dapat diketahui sehingga dapat dihindari kemungkinan terjadinya perselisihan.

2) Upah

Upah adalah sesuatu yang wajib diberikan olehpemyewa sebagai kompensasi dari manfaat yang ia dapatkan. Semua yang dapat digunakan sebagai alat tukar dalam jual beli boleh digunakan untuk pembayaran dalam ijarah. Upah atau pembayaran harus diketahui meskipun masih terhutang dalam tanggungan, seperti dirham, barang-barang yang ditakar atau di timbang, dan barang-barang yang dapat dihitung. Karena itu, harus dijelaskan jenis, macam, sifat, dan ukurannya. ${ }^{28}$

Manfaat yang telah diperoleh oleh penyewa, wajib di bayarkan upahnya oleh penyewa, yaitu yang telah ditetapkan oleh orang yang ahli dalam bidangnya. Ijarah hanya mempunyai satu rukun, yaitu shighah. Adapun muta'aqidain dan ma'qud'alaih merupakan pihak-pihak penyangga transaksi karena transaksi tidak akan terlaksana kecuali dengan adanya dua pihak ini. ${ }^{29}$

\section{b. Syarat Ijarah}

Untuk sahnya sewa menyewa (ijarah) pertama kali harus dilihat terlebih dahulu adalah orang yang akan melakukan perjanjian sewa menyewa tersebut, yaitu apakah kedua belah pihak telah memenuhi syarat untuk melakukan perjanjian pada umumnya.

Unsur yang terpenting untuk diperhatikan yaitu kedua belah pihak cakap bertindak dalam hukum yaitu punya kemampuan untuk dapat embedakan yang baik dan yang

${ }^{28}$ Abdullah bin Muhammad Ath-Thayyar, OP., Cit., h. 318

${ }^{29}$ Ibid, h. 318 
buruk (berakal), Imam Syafi'I dan Imam Hambali menambahkan satu syarat lagi, yaitu dewasa (baligh), perjanjian sewa menyewa yang dilakukan oleh orang yang belum dewasa menurut mereka adalah tidak sah, walaupun mereka sudah berkemampuan untuk membedakan mana yang baik dan mana yang buruk (berakal). ${ }^{30}$

Sedangkan menurut Faturrahman Djamil dalam buku Hukum perjanjian dalam transaksi menjelaskan bahwa untuk sahnya perjanjian sewa menyewa (ijarah) harus terpenuhu syarat-syarat sah sebagai berikut $:^{31}$

1) Adanya keridaan dari kedua pihak yang akad. Kedua belah pihak yang berakad menyatakan kerelaannya untuk melakukan akad ijarah. Artinya kalau di dalam perjanjian sewa menyewa itu terdapat unsur paksaan, maka sewa meyewa itu tidak sah. Firman Allah SWT dalam surat An-Nisa ayat 29

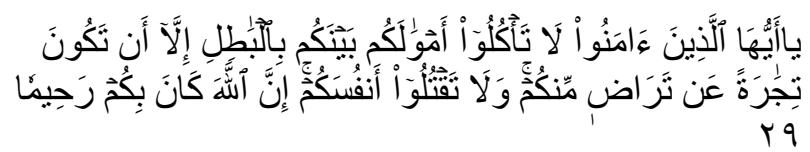

Artinya :"Hai orang-orang yang beriman, janganlah kamu saling memakan harta sesamamu dengan cara yang bathil, kecuali dengan jalan perniagaan yang berlaku dengan dasar suka sama suka diantara kamu..."(QS. An-Nisa: 29)

2) Manfaat yang menjadi objek ijarah harus diketahui secara sempurna, sehingga tidak muncul perselisihan di kemudian hari. Harus jelas dan terang mengenai objek yang diperjanjikan, maksutnya harus jelas dan terang mengenai obyek sewa menyewa, yaitu barang yang dipersewakan disaksikan sendiri, termasuk juga masa sewa (lama

3) waktu sewa menyewa berlangsung dan besarnya uang sewa yang diperjanjian).

${ }^{30}$ Rahmat Syafe'I, OP.,Cit., h. 125

${ }^{31}$ Fathurrahman Djamil, OP.,Cit., h. 154 
4) Objek ijarah dalam bentuk jasa atau tenaga orang lain (ijarah'ala al-amal) bukan merupakan suatu kewajiban individual (fardhu 'ain) bagi orang tersebut seperti shalat atau puasa. Obyek sewa menyewa dapat digunakan sesuai peruntukannya. Maksudnya kegunaan barang yang disewakan itu harus jelas, dan dapat dimanfaatkan oleh penyewa sesuai dengan peruntukannya (kegunaan) barang tersebut, andainya barang itu tidak dapat digunakan sebagaimana yang diperjanjikan maka perjanjian sewa menyewa itu dapat dibatalkan.

Dan dalam hal kontrak kerja dapat diartikan hasil suatu pekerjaan yang telah dikerjakan itu sesuai dengan yang telah diperjanjikan sebelumnya, sehingga pengusaha merasa tidak dirugikan.

5) Penyewa barang berhak memanfaatkan barang sewaan tersebut, baik untuk diri sendiri maupun untuk orang lain dengan cara menyewakan atau meminjamkan.

6) Objek ijarah dalam bentuk barang merupakan sesuatu yang dapat disewakan

7) Imbalan sewa atau upah harus jelas, tertentu dan bernilai.

Syarat ijarah terdiri dari empat macam, sebagaimana syarat dalam jual beli yaitu : ${ }^{32}$

1) Syarat Terjadinya Akad

Sebagaimana telah dijelaskan dalam jual beli, menurut ulama Hanafiyah, aqid disyaratkan harus berakal dan mumayyiz (minimal 7 tahun), serta tidak disyaratkan harus baligh. Akan tetapi, jika bukan barang miliknya sendiri, akad ijarah anak mumayyiz di pandang sah bila telah diizinkan walinya.

Ulama Malikiyah berpendapat bahwa tamyiz adalah syarat ijarah dan jual beli, sedangkan baligh

${ }^{32}$ Rachmat Syafe'I, OP.,Cit., h. 127 
adalah syarat penyerahan. Dengan demikian, akad anak mumayyiz adalah sah, tetapi bergantung atas keridaan walinya. Sedangkan menurut ulama Hanabilah dan Syafi'iyah mensyaratkan orang yang akad harus mukallaf, yaitu baligh dan berakal, sedangkan anak mumayyiz belum dapat dikategorikan ahli akad. ${ }^{33}$

2) Syarat Pelaksanaan (an-nafadz)

Agar ijarah terlaksana, barang harus dimilki oleh aqid atau ia memiliki kekuasan penuh untuk akad (ahli). Dengan demikian ijarah al-fudhul (ijarah yang dilakukan oleh orang yang tidak memiliki kekuasaan atau tidak diizinkan oleh pemiliknya) tidak dapat menjadikannya ijarah.

3) Syarat sah Ijarah

Keabsahan ijarah sangat berkaitan dengan 'aqid (orang yang akad), ma'qud'alaih (barang yang menjadi objek akad), ujrah (upah), dan zat akad (nafs al-'aqad).

4) Syarat kelaziman yaitu :

Syarat kelaziman ijarah terdiri atas dua hal,

a) Ma'qud'alaih (barang sewaan) terhindar dari cacat.

Jika terdapat cacat pada ma'qud'alaih (barang sewaan), penyewa boleh memilih antara meneruskan dengan membayar penuh atau membatalkan.

b) Tidak ada uzur yang dapat membatalkan akad.

Ulama Hanafiyah berpendapat bahwa ijarah batal karena adanya uzur sebab kebutuhan atau manfaat akan hilang apabila ada uzur. Uzur yang dimaksut adalah sesuatu yang baru yang menyebabkan kemadaratan bagi yang akad. Uzur

${ }^{33}$ Ibid, h. 128 
dikategorikan menjadi tiga macam, yaitu pertama, uzur dari pihak penyewa, seperti berpindah-pindah dalam mempekerjakan sesuatu sehingga tidak menghasilkan sesuatu atau pekerjaan menjadi siasia. Kedua, uzur dari pihak yang disewa, seperti barang yang disewakan harus dijual untuk membayar utang dan tidak ada jalan lain, kecuali menjualnya. Ketiga, uzur pada barang yang disewa, seperti menyewa kamar mandi, tetapi menyebabkan penduduk dan semua penyewa harus pindah. $^{34}$

\section{c. Hal-hal yang Membatalkan Ijarah}

Pada dasarnya perjanjian sewa menyewa (ijarah) adalah merupakan perjanjian yang lazim, di mana masing-masing pihak yang terkait dalam perjanjian itu tidak mempunyai hak untuk membatalkan perjanjian, karena jenis perjanjian termasuk kepada perjanjian timbal balik.

Bahkan jika salah satu pihak (yang menyewakan atau penyewa) meninggal dunia, perjanjian sewa menyewa tidak akan menjadi batal asalkan saja yang menjadi obyek perjanjian sewa menyewa masih tetap ada. Sebab dalam hal salah satu pihak meninggal dunia maka kedudukannya digantikan oleh ahli waris, apakah dia sebagai pihak yang menyewakan ataupun juga sebagai pihak penyewa. ${ }^{35}$

Adapun hal-hal yang menyebabkan batalnya perjanjian sewa menyewa (ijarah) adalah disebabkan sebagai berikut :

a. Terdapat cacat pada barang yang disewakan

Maksudnya bahwa barang yang menjadi obyek perjanjian sewa menyewa terdapat kerusakan ketika sedang berada di tangan pihak penyewa yang mana kerusakan itu adalah diakibatkan kelalaian pihak penyewa sendiri, misalnya karena penggunaan barang tidak sesuai dengan peruntukan penggunaan barang tersebut. Dalam hal pekerjaan ini dapat diartikan bahwa seorang pekerja lalai dalam melakukan pekerjaan

${ }^{34}$ Rachmat Syafe'I , Ibid, h. 129-130

35 Drs. H. Chairuman Pasaribun dan Suhrawardi K.Lubis, SH. Hukum Perjanjian dalam Islam, Jakarta : Sinar Grafika, 1996, h. 57 
sehingga fasilitas-fasilitas yang digunakan untuk bekerja mengalami kerusakan yang diakibatkan oleh pekerja itu sendiri.

\section{b. Rusaknya barang yang disewakan}

Maksud barang yang menjadi obyek perjanjian sewa menyewa mengalami kerusakan atau sama sekali sehingga tidak dapat dipergunakan lagi sesuai dengan apa yang diperjanjikan. Dalam hal kontrak kerja penulis mengartikan bahwa seorang pekerja mendapat suatu pekerjaan yang telah dijanjikan sebelumnya, semisal seorang sopir dijanjikan akan mendapat mobil yang bagus tetapi kenyataannya mendapat mobil yang rusak sehingga tidak dapat dipergunakan sebagaimana mestinya.

\section{c. Rusaknya barang yang diupahkan}

Maksudnya barang yang menjadi sebab terjadinya hubungan sewa menyewa mengalami kerusakan, karena dengan rusaknya atau musnahnya barang menyebabkan terjadinya perjanjian maka akad tidak akan mungkin terpenuhi lagi.

Kontrak kerja penulis mengartikan bahwa seorang pengusaha akan mengakhiri perjanjian apabila hasil karya seorang pekerja mengalami kerusakan atau tidak sesuai dengan kesepakatan sebelumnya.

\section{d. Dasar Hukum Ijarah}

\section{Al-Qur'an}

Qs $_{\text {e }}$ Al- Baqarah ayat 233 :

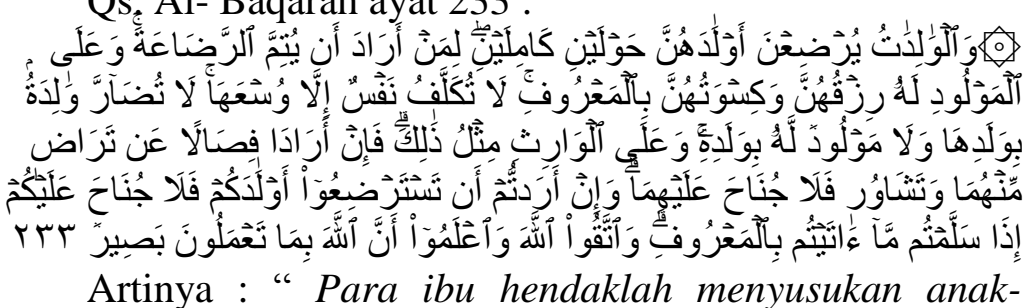

anaknya selama dua tahun penuh, Yaitu bagi yang ingin menyempurnakan penyusuan. dan kewajiban ayah memberi Makan dan pakaian kepada Para ibu dengan cara ma'ruf. 
seseorang tidak dibebani melainkan menurut kadar kesanggupannya. janganlah seorang ibu menderita kesengsaraan karena anaknya dan seorang ayah karena anaknya, dan warispun berkewajiban demikian. apabila keduanya ingin menyapih (sebelum dua tahun) dengan kerelaan keduanya dan permusyawaratan, Maka tidak ada dosa atas keduanya. dan jika kamu ingin anakmu disusukan oleh orang lain, Maka tidak ada dosa bagimu apabila kamu memberikan pembayaran menurut yang patut. bertakwalah kamu kepada Allah dan ketahuilah bahwa Allah Maha melihat apa yang kamu kerjakan."

Pada surat Al-Baqarah diatas menjadi dasar hukum adanya sistem sewa dalam hukum islam. Seperti yang diungkapkan dalam ayat bahwa seseorang itu boleh menyewa orang lain untuk menyusui anaknya, tentu saja ayati akan berlaku umum terhadap segala bentuk sewa-menyewa. ${ }^{36}$

\section{Hadis}

Para ulama mengemukakan alasan kebolehan ijarah berdasarkan hadits, diantaranya yaitu :

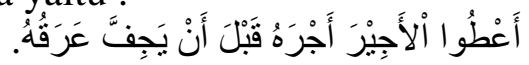

Dari Ibnu Umar, bahwa Rasulullah saw bersabda ; "berikanlah upah pekerja sebelum keringatnya kering". (HR. Ibn Majah).

Hadis di atas menjelaskan tentang ketentuan pembayaran upah terhadap orang yang dipekerjakan, yaitu Nabi sangat menganjurkan agar dalam pembayaran upah itu hendaknya sebelum keringatnya kering atau setelah pekerjaan itu selesai dilakukan. ${ }^{37}$

Hadis di atas juga Menerangkan bahwa seorang pengusaha harus bertanggung jawab dalam pembayaran upah pekerja sesuai dengan kesepakatan yang telah dibuatnya.

\section{e. Hukum Menahan Upah Pegawai}

Wajib bagi orang yang mempekerjakan seseorang untuk memberikan upah kalau dia sudah menunaikan pekerjaannya tanpa diundur-undur. Karena ia telah

${ }^{36}$ Fathurrahman Djamil, OP.,Cit., h. 152

${ }^{37}$ Abdullah bin Muhammad Ath-Thayya, Ibid, h. 153 
menunaikan pekerjaannya maka wajib menyerahkan upahnya. Haram menahan upah pegawai. Barangsiapa menahannya atau memakannya maka Allah akan menjadi musuhnya pada hari kiamat (Mausuah al-fiqh al-Islami, 3:534).

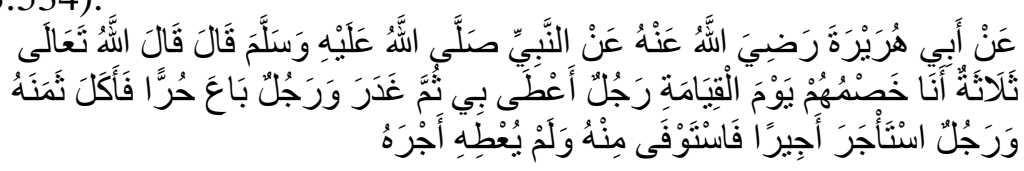

Artinya: Dari Abu Hurairah radliallahu 'anhu dari Nabi shallallahu 'alaihi wasallam bersabda: "Allah Ta'ala berfirman: Ada tiga jenis orang yag aku berperang melawan mereka pada hari qiyamat, seseorang yang bersumpah atas namaku lalu mengingkarinya, seseorang yang berjualan orang merdeka lalu memakan (uang dari) harganya dan seseorang yang memperkerjakan pekerja kemudian pekerja itu menyelesaikan pekerjaannya namun tidak dibayar upahnya”. (HR.al-Bukhari)

\section{Analisis}

\section{Analisis Proses Terjadinya Upah jasa Pengairan Sawah di Kota Metro}

Pelaksanaan ijab qabul dalam Upah jasa pengairan terjadi secara lisan. Upah jasa ditentukan oleh kesepakatan kedua belah pihak. Hal ini dilakukan bersama-sama dengan cara pihak pengelola irigasi mengumpulkan masyarakat petani disalah satu gedung atau balai desa, kemudian masyarakat dalam pertemuan tersebut melakukan ijab qabul

Berdasarkan data yang penulis dapatkan, pelaksanan ijab qabul tersebut telah sesuai dengan unsure-unsur akad yaitu :

a. Apabila dilihat dari segi orang yang berakad, yang menjadi pihak dalam perjanjian ini pihak petani pemilik tanah sebagai pihak pertama dan pihak pengelola irigasi sebagai pihak kedua.

b. Apabila dilihat dari shiqhatnya atau ijab qabul, maka yang menjadi shiqhat dari perjanjian ini berbentuk tulisan, yakni dari pihak petani pemilik tanah yang meminta pengelola irigasi agar mengairi sawah dan pihak pengelola irigasi menerima ucapan tersebut. 
c. Apabila dilihat dari segi objek akadnya, maka yang menjadi objek dalam perjanjian ini adalah tenaga pekerja atau ketrampilannya dalam pengairan sawah.

d. Apabila dilihat dari segi maudhu'ul'aqdi atau tujuan akad, maka yang menjadi tujuan akad adalah terkandung harapan saling memperoleh keuntungan dari perjanjian akad dalam pengairan sawah dan sekaligus mempunyai manfaat tersendiri baik dari pihak petani ataupun dari pihak pengelola irigasi.

Berdasarkan pada letak geografis dan keadaan social ekonomi masyarakat Kota Metro, yang mayoritas petani, baik petani pemilik sawah maupun petani penggarap, maka sudah sewajarnya jika masyarakat petani tersebut sangat membutuhkan adanya air untuk memenuhi kebutuhan mereka dalam bercocok tanam.

Adanya pihak yang menyediakan irigasi pengairan, kebutuhan masyarakt petani akan air dapat terwujud dengan cara melakukan kerjasama antara keduanya. Kerjasama dilakukan untuk memperoleh keuntungan, pihak petani memperoleh keuntungan berupa tersedianya air dalam bercocok tanam, sehingga mereka tidak lagi mengandalkan air hujan, sedangkan pihak irigasi memperoleh keuntungan upah jasa (5 kg padi dan uang sebesar Rp. 2500 dari $114 \mathrm{bau}$ ) dari hasil panen. Sehingga pelaksanaan kerjasama yang terjadi dalam pengairan sawah tersebut merupakan al-umur al-hajiyah yakni hal-hal yang sangat dihajatkan oleh manusia sebagai usaha untuk menghilangkan kesulitan-kesulitan dan menolak halangan.

Kesulitan air pada masyarakat petani dalam bercocok tanam tersebut dapat berpengaruh pada kelangsungan hidup masyarakat yang mayoritas berpenghasilan dari pertanian, sesuai dengan kesepakatan bahwa pada waktu panen, petani memberikan $5 \mathrm{~kg}$ padi dan uang sebesar Rp.2500 dari 114 bau kepada pihak pengelola irigasi sebagai upah atau ujrah. Pembagian tersebut dilakukan ketika petani sudah panen. Aturan pembagiannya ialah dengan cara pihak petani mendatangi rumah pengelola irigasi untuk memberikan $5 \mathrm{~kg}$ padi dan uang sebesar Rp.2500 dari $1 \backslash 4$ bau. Aturan pembagian seperti diatas selama ini tidak pernah 
menimbulkan masalah dan telah menjadi kesepakatan kedua belah pihak.

Akad jasa yang terjadi di kota metro tersebut tidak mengenal adanya jatuh tempo atau batasan waktu, perjanjian tersebut dianggap habis atau berakhir ketika pembagian masing-masing sudah ditentukan dan masyarakat menyetujui hasil pembagian tersebut.

\section{Analisis Hukum Ekonomi Syariah Terhadap Akad Jasa di Kota Metro.}

Konsep Islam adalah menjujung kebebasan kepada masyarakat untuk bermuamalah dalam segala aspek kehidupan. Ini menunjukkan ajaran Islam sangat akomodatif terhadap perkembangan peradaban manusia dari masa kemasa.

Sebagai sistem kehidupan, Islam memberikan warna dalam setiap dimensi kehidupan manusia, tak terkecuali dunia ekonomi. Sistem islam ini berusaha mendialektikan nilai-nilai ekonomi dengan nilai akidah ataupun etika. Kegiatan ekonomi yang dilakukan oleh masyarakat di Kota metro dengan nilai materialisme dan spiritualisme. Kegiatan ekonomi yang dilakukan oleh masyarakat Kota metro bukan hanya berbasis nilai materi, akan tetapi terdapat sandaran transidental di dalamnya, sehingga akan bernilai ibadah. selain itu , konsep terhadap nilai-nilai humanisme.

Prinsip dasar dalam persoalan muamalah adalah untuk mewujudkan kemaslahatan umat manusia, dengan memperhatikan dan mempertimbangkan berbagai situasi dan kondisi yang mengitari manusia itu sendiri.

Salah satu kegiatan masyarakat Kota Metro yang dilakukan adalah ijarah, yaitu suatu akad yang berisi penukaran manfaat sesuatu dengan jalan memberikan imbalan dalam jumlah tertentu ini dapat dikategorikan kedalam kontrak kerja. Ijarah mempunyai peranan penting dalam kehidupan sehari- hari, karena kita tidak sanggup mengerjakan dan menyelesaikan urusan kita dengan kemampuan kita sendiri. Karena masyarakat Kota Metro perlu menyewa tenaga atau mempekerjakan orang lain yang mampu melakukannya dengan imbalan pembayaran yang 
disepakati oleh kedua belah pihak atau menurut adat kebiasaan yang berlaku.

Penulis menganalisis terjadinya akad jasa ini belum memenuhi rukun dan syarat ijarah, yaitu terjadinya pelanggaran yang dilakukan salah satu pihak yang merugikan pihak lain, yaitu adanya upah yang harus menjadi hak dari pengelola irigasi tidak diberikan meskipun dari pihak petani telah panen. Adanya permasalahan yang terjadi dalam masyarakat yang terkait dengan penanggulangan upah, menyebabkan ketidak sempurnaan akad ijarah yang telah disepakati oleh kedua belah pihak.

Keridhoan adalah hal yang sangat penting dalam setiap muamalah dan janganlah memperoleh sesuatu dengan jalan yang batil. Perjanjian atau akad merupakan faktor yang sangat penting dalam sebuah transaksi, dimana dipandang tidak dari zhahirnya saja,akan tetapi batin akad juga perlu diperhatikan. Batin akad adalah keridhoan ataupun kerelaan serta tidak adanya unsur keterpaksaan, jika zhahir akad tidak sah maka otomatis batin akad juga tidaklah sah.

Keridhoan dalam transaksi adalah merupakan prinsip, oleh karena itu transaksi barulah dianggap sah apabila didasarkan keridhoan kedua belah pihak. Artinya tidak sah apabila salah satu pihak dalam keadaan terpaksa atau dipaksa atau merasa tertipu, bisa terjadi pada waktu akad meridhoi, tetapi kemudian salah satu pihak merasa tertipu, maka akad tersebut bisa batal.

Penangguhan upah dalam pengairan sawah yang terjadi di Kota Metro, dimana pihak pemilik sawah telah melalaikan kewajibannya tersebut, karena secara zhahir tidak memberikan upah kepada pekerja yang telah menyelesaikan pekerjaannya, selain itu secara batin jelas salah satu pihak merasa terzhalimi dan tentu membuat sakit hati serta ketidak ridhoan mengingat upah yang seharusnya didapatkan tetapi tidak didapatkan. Keterlambatan pembayaran upah tersebut berarti batin akad tidak bisa terpenuhi.

Gamabaran bijak adalah tentang rasa dalam bermuamalah tidak berdusta dalam masalah laba dengan cara-cara yang tidak wajar. Pekerja dalam islam adalah suatu kewajiban bagi mereka yang mampu, tidak dibenarkan bagi seorang muslim berpangku tangan dengan alasan 
"mengkhususkan waktu untuk ibadah" atau bertawakal kepada Allah SWT, tidak dibenarkan pula bagi muslim untuk bersandar pada bantuan orang lain sedang ia mampu dan memiliki kemampuan. Pekerjaan apapun sehrusnya diniati dengan ibadah sehingga segala sesuatu prilaku dan tatacara bekerja serta menjalin kerjasama sesuai dengan nilai-nilai islam. Segala sesuatu yang diniatkan untuk beribadah serta mendapat ridho Allah maka, hal-hal yang dilarang oleh syara' tentunya akan datang, karena semua perbuatan yang diperbuat di dunia kelak akan dipertanggungjawabkan di akhirat.

Akad jasa yang terjadi di Kota Metro bila ditinjau dari teori ijarah yaitu dengan persewaan tenaga untuk mengairi sawah selama masa menanam sampai masa panen, tetapi dengan adanya pelanggaran akad yang dilakukan salah satu pihak menyebabkan rukun ijarah menjadi tidak sempurna dan menjadi akad yang fasid.

\section{Kesimpulan}

Setelah mengkaji, menganalisis dan menelaah kasus pengupahan dalam pengairan sawah di kota Metro, maka dari uraian tersebut di atas, ada beberapa hal yang dapat disimpulkan, yaitu :

1. Pelaksanaan akad jasa yang terjadi di Kota Metro merupakan salah satu bentuk dari kerjasama yang boleh dilakukan. Tersedia air pada masyarakat petani dalam bercocok tanam dapat berpengaruh dalam kelangsungan hidup mereka yang mayoritas berpenghasilan dari pertanian, sehingga terjadinya kerjasama dalam pengairan sawah di kota metro merupakan al-umur alhajiyah dan juga merupakan kebutuhan yang ditempatkan pada tempat yang darurat. Dengan pola pembayaran $5 \mathrm{~kg}$ padi dan uang sebesar Rp.2500 (dari 114 bau) dan diberikan setelah panen.

2. Akad jasa yang telah terjadi di Kota Metro bila ditinjau dari teori ijarah adalah suatu akad yang berisi penukaran manfaat sesuai dengan jalan pemberian imbalan dalam jumlah tertentu yang dalam hal ini dapat dikategorikan kedalam kontrak kerja. Yaitu penukaran tenaga untuk 
mengairi sawah mulai dari awal penanaman padi sampai padi siap panen. penangguhan upah yang seharusnya di berikan sesuai dengan akad perjanjian akad ijarah , tetapi pada kenyataanya upah tersebut tidak diberikan kepada pekerja yang telah melakukan pekerjaann, pelanggaran yang dilakukan salah satu pihak tersebut membuat akad menjadi fasid dan tidak sahih, sehingga membuat ketidak sempurnaan akad.

\section{Daftar Pustaka}

A Mudjab Mahali, Asbabun nuzul : Studi Pendalaman alQur'an surat al-Baqarah-an-Nas, Jakarta : Raja Grafindo Persada. 2002

Abdul Aziz Dahlan, et.al., Ensiklopedi Hukum Islam, (Jakarta : Ichtiar Bru Van Hove, jilid 5)

Abdullah bin Muhammad Ath-Thayyar, Abdullah bin Muhammad Al-Muthlaq, Muhammad bin Ibrahim, Ensiklopedi Fiqih Muamalah (dalam pandangan 4 madzhab).

Abdullah Rahman Ghazali, Fiqih Muamalah, (Jakarta:Kencana Prenada Media Group.2002)

Abu Ishaq bin Ali bin Yusuf al-Firazi Abdi al-Syirazi, alMuhazzab, Libanon : Dar al-F M. Iqbal Hasan, Pokokpokok Materi Metodologi Penelitian dan Aplikasinya, Jakarta : Ghalia indonesia, 2002

Abuddin Nata, Metodologi Studi Islam , (Jakarta: Rajawali Pers,2010)

Ahmad Azhar Basyri, Asas-Asas Hukum Muamalah, (Yogyakarta : UII Press, 2012)

Beni Ahmad Saebani, Metode Penelitian, (Bandung: Pustaka setia, 2008) 
Cholid Narbuko, Abu Achmadi, Metodologi Penelitian, Cet. 9, Jakarta : Bumi Aksara, 2008

Cholid Narbuko, Abu Achmadi, Metodologi Penelitian, Cet.9, (Jakarta : Bumi Aksara, 2008)

Dedy Mulyana, Metodologi Penelitian Kualitatif, (Bandung : Remaja Rosda Karya, 2004)

Dimyauddin Djuwan, Pengantar Fiqih Muamalah, (Yogyakarta: Pustaka Pelajar, Cet.Pertama,2008)

Fathurrahman Djamil, Hukum Perjanjian dalam Transaksi di LKS, (Jakarta: Sinar Grafika, 2012

Sinar Grafika, 2013)

Gemala Dewi, hukum Perikatan Islam, (Jakarta : Kencana, 2006)

Ghufron A, Mas'adi, Fiqih Muamalah Kontekstual, (Jakarta; Raja Grafindo Persada, 2002)

HA. Hafizh Dasuki, Ensiklopedia Hukum Islam, (Jakarta: PT Ichtiar Baru van Hoeven, 1997)

Hasbi As Shiddieqy, Pengantar Fiqh Mu'amalah, (Semarang : Pustak Rizki Putra, 1997, Cet 1)

Hendi Suhendi, Fiqih Muamalah, cet.ke-6 (Jakarta , Raja Grafindo Persada, 2010).

Himpunan Undang-Undang dan Peraturan Pemerintah, (Yogyakarta :Pustaka Zeedny, 2009)

Husain Usman dan Purnomo Setiady Akbar, Metodologi Penelitian Sosial, Jakarta : Bumi Aksara, 2000,

Ija Suntana, Politik Ekonomi Islam, (Bandung: CV Putaka Setia, 2010) ikr, 1994, Juz ke-1, 
Imam Abi Hasan Ali Ahmad al-Wahidi, Asbabun nuzul, libanon: Dar- al-Kutub al-Ilmiyah, 1998

Ismail Nawawi, Fiqih Muamalah Klasik dan Kontemporer, (Bogor: Galia Indonesia, 2012)

Jeffri Edmund Curry, Memahami Ekonomi Internasional, (Jakarta; PPM, 2001), Cet.1

Karnaen Parwaatmadja, M.Syafi'I Antonio, Prinsip Ekonomi Islam, (Piblicia Jakarta, 1990)

Lexy Moloeng, Metodologi Penelitian Kualitatif, ( Bandung : Remaja Rosdda Karya, 1990)

M. Abdul Manan, Teori dan Praktek Ekonomi Islam, (Yogyakarta: PT. Dana Bhakti Prima Yasa, 1997)

M. Damar Raharja, Islam dan Trasformasi Sosial Ekonomi, (Jakar; Lembaga Studi Agama dan Filsafat,1999)

M. Iqbal Hasan, Pokok-pokok Materi Metodologi Penelitian dan Aplikasinya, Jakarta : Ghalia indonesia, 2002,

Mardani, Fiqih EkonomiSyariah, (Jakarta:Kencana, 2012)

Masri Singaribun dan Sofian Effendi, Metode Penelitian Survei, Yogyakarta : Pusat Penelitian dan studi kependudukan Universitas Gajah Mada, 1981

Muhammad Amin, Tanwirul Qulub, Indonesia: al-Haromain Jaya, 2006

Muhammad Saddam, Ekonomi Islam, Terjemah Hary Kurniawan (Jakarta ; Taramedia, 2003)

P3EI Universitas Islam Indonesia Yogyakarta, Ekonomi Islam,( Jakarta; Rajawali Pers, 2012)

Rahmat Syafe'I, Fiqih muamalah, cet. Ke-3, (Bandung, pustaka setia,2006) 
Saifuddin Azwar, Metodologi Penelitian, Yogyakarta: Pustaka Pelajar, 1999,

Sayyid Sabiq, Fiqhus-Sunnah, Kairo: Darel-Fath, 2009

Sayyid Sabiq, Fiqih Sunnah Juz 13, alih bahasa H.kamaluddin A.Marzuki, (Bandung:Al-Ma'arif, 1988)

Shahih Bukhari, Terjemahan Hadis jili I, (Jakarta : PT. Bumi Restu, 1992)

Sohari Sahari, dan Ru'fah Abdullah, Fikih Muamalah, (Bogor: Ghalia Indonesia, 2011)

Sumadi Suryabrata, Metodologi Penelitian, Jakarta : Rajawali Press, 1990

Sumardi Suryabrata, Metodologi Penelitian, (Jakarta: Rajawali Press, 1990)

Undang-undang Nomor 77 Tahun 2001 tentang Irigasi. Pasal 1 ayat (3) dan Pasal 5 ayat (1). 
134 Ambariyani dan Wiwik Damayanti: Praktik Ijarah Jasa.......

Mahkamah, Vol. 2, No. 1, Juni 2017 